\title{
Kelekatan (Attachment) pada Ibu dan Ayah Dengan Kompetensi Sosial pada Remaja
}

\author{
Rika Aulya Purnama, Sri Wahyuni \\ Fakultas Psikologi Universitas Islam Negeri Sultan Syarif Kasim Riau \\ email: sri.wahyuni@uin-suska.ac.id
}

\begin{abstract}
Abstrak
Penelitian ini bertujuan untuk mengetahui hubungan antara kelekatan (attachment) pada ibu dan ayah dengan kompetensi sosial pada remaja. Kompetensi sosial yang dimaksud adalah kemampuan dan keterampilan yang dimiliki oleh seseorang dalam berinteraksi dengan orang lain untuk mencapai hubungan sosial yang positif, sedangkan kelekatan merupakan ikatan emosional yang terbentuk antara individu dengan orangtua atau pengasuh yang terjadi sejak bayi. Subjek dalam penelitian ini adalah remaja di SMPN 21 Pekanbaru yang berusia 12-15 tahun, yang ditentukan melalui teknik cluster random sampling. Skala yang digunakan dalam penelitian ini berupa skala psikologis yaitu skala kelekatan (attachment) menggunakan Inventory of Parent and Peer Attachment (IPPA) yang telah dimodifikasikan oleh Wahyuni dan Asra (2014) dan skala kompetensi sosial menggunakan skala yang dimodifikasikan oleh Rahman (2010) berdasarkan teori Gresham dan Elliott. Berdasarkan analisis korelasi regresi linier berganda menunjukkan bahwa terdapat hubungan antara kelekatan (attachment) pada ibu dan ayah dengan kompetensi sosial pada remaja $(F=5,444 ; R=$ $0,229 ; p=0,005)$. Kelekatan pada ibu dan ayah memiliki kontribusi sebesar $5,3 \%$ terhadap kompetensi sosial.
\end{abstract}

Kata kunci : kelekatan (attachment) pada ibu dan ayah, kompetensi sosial

\section{Attachment to Mothers and Fathers and Social Competence on Adolescents}

\begin{abstract}
The purpose of this study is to identify the relationship between attachment to mothers and fathers and social competence in adolescents. Social competence in question is the ability and skills possessed by a person in interacting with others to achieve positive social relationships, while the attachment is an emotional bond that is formed between the individual with the parent or caregiver that occurs since the baby. The participants of this study were adolescents at SMPN 21 Pekanbaru, aged 12-15 years, determined by cluster random sampling technique. The scale used of this research is psychological scale: Attachment scale using Inventory of Parent and Peer Attachment (IPPA) which has been modified by Wahyuni and Asra (2014) and social competency scale using scale modified by Rahman (2010) based on theory Gresham and Elliott. Based on multiple linear regression correlation analysis showed that there is correlation between attachment to mother and father and social competence in adolescent $(F$ $=5,444 ; R=0,229 ; p=0,005)$. Attachment to mothers and fathers has a $5.3 \%$ contribution to social competence.
\end{abstract}

Keywords: attachment to mother and father, social competence

\section{Pendahuluan}

Remaja adalah suatu fase perkembangan yang dialami oleh semua manusia. Stanley Hall menjelaskan bahwa masa remaja terjadi antara usia 12 sampai 23 tahun dan merupakan masa yang penuh dengan topan dan tekanan, masa pergolakan yang dipenuhi oleh konflik dan perubahan suasana hati (Santrock, 2007), dan disebut juga sebagai masa transisi dari masa anak-anak menuju masa dewasa yang mengandung perubahan besar baik secara fisik, kognitif, maupun psikososial (Papalia dkk, 2008). Perubahan secara sosial yang dialami oleh remaja ditandai dengan perubahan-perubahan untuk mencapai kematangan dalam hubungan sosial atau perubahan untuk dapat menyesuaikan diri dengan norma-norma yang diberlakukan dalam suatu kelompok (Yusuf, 2012). Menurut Rahman (2010) perubahanperubahan dalam fisik, mental-psikis serta sosial dapat menyebabkan kegoncangan dalam diri remaja sehingga seringkali menampilkan 
perilaku yang buruk atau bahkan menyimpang dari norma-norma.

Dewasa ini permasalahan remaja masih menjadi pusat perhatian dari berbagai kalangan masyarakat, seperti kasus kenakalan remaja meningkat menjadi $36,66 \%$ pada tahun 2012 yang meningkat menjadi 41 kasus (Pekanbaru Tribunnews.com, 2012), pencurian (Repubika.co.id, 2013), penyalahgunaan narkoba (Sindonews.com, 2014) dan pengeroyokan (Tempo.com, 2015). Hair, Jarget, dan Garret (2001) mengemukakan bahwa remaja yang menggunakan narkoba, memiliki harga diri yang rendah, kesepian, memiliki masalah kesehatan mental dan nakal menunjukkan kurangnya kompetensi sosial.

Permasalahan remaja yang dijelaskan di atas terjadi karena remaja yang kurang memiliki kompetensi sosial kurang memiliki sifat asertif sehingga akan mudah terpengaruh oleh teman sebaya, tidak dapat bertahan ditengah-tengah keberbedaannya dengan lingkungan akan membiarkan diri tenggelam dalam kesamaan identitas lingkungan teman sebayanya, seperti penyalahgunaan narkoba (Anindyajati \& Karima, 2004). Remaja merasa takut untuk ditolak oleh teman sebayanya, karena penolakan dan pengabaian dari teman sebaya juga dapat menyebabkan munculnya perasaan kesepian, masalah kesehatan mental dan kejahatan (Desmita, 2012). Selain itu, remaja yang kurang memiliki kompetensi sosial juga terlihat pemalu sehingga ia mengalami kesulitan dalam bergaul (Ramdhani, 1996).

Kurangnya kompetensi sosial akan menyulitkan remaja untuk mencapai hubungan yang baik dengan individu lain. Hal ini dikarenakan pada kehidupan sosial remaja diharapkan untuk dapat bergaul dan menjalin hubungan dengan individu lain yang didasarkan atas rasa saling menghargai dan menghormati. Sebagaimana tugas perkembangan yang harus diselesaikan oleh remaja yakni mencapai hubungan baru dan lebih matang dengan teman sebaya baik pria maupun wanita (Havighurst, dalam Yusuf 2012). Havighurst juga menjelaskan bahwa seseorang yang gagal dalam menuntaskan tugas perkembangan maka akan menyebabkan ketidakbahagiaan, menimbulkan penolakan dari masyarakat dan individu akan kesulitan dalam menuntaskan tugas-tugas pada periode berikutnya (Yusuf, 2012).

Kompetensi sosial sangat penting bagi remaja karena dengan adanya kompetensi sosial, remaja dapat menyesuaikan diri dengan lingkungan sekitar dan berperilaku secara tepat sesuai dengan norma-norma yang ada dalam masyarakat (Anggraini \& Wahyuningsih, 2007). Individu yang memiliki kompetensi sosial mampu memperoleh respon positif dari orang lain dan terampil dalam membentuk hubungan yang akrab dan saling mendukung (Smart \& Sanson, 2003), mampu menghadapi konflik dalam interaksi sosial (Santoso, 2011). Kompetensi sosial penting dalam memprediksi perkembangan sosial individu (Renk \& Phares, 2004).

Gresham dan Elliott (dalam Smart \& Sanson, 2003) menjelaskan bahwa ada beberapa aspek yang menggambarkan kompetensi sosial yaitu 1). asertif, yaitu perilaku yang berinisiatif seperti menanyakan kepada orang lain mengenai informasi, memperkenalkan diri sendiri, dan menanggapi tindakan orang lain; 2). kooperatif, yaitu perilaku seperti membantu orang lain, berbagi tentang suatu hal, dan patuh terhadap peraturan dan permintaan; 3 ). empati, yaitu perilaku yang menunjukkan perhatian dan menghormati perasaan dan sudut pandang orang lain; 4). tanggung jawab, yaitu perilaku yang menunjukkan kemampuan untuk berkomunikasi dengan orang dewasa dan menghormati kepemilikan benda atau pekerjaan; dan 5). pengendalian diri, yaitu perilaku yang muncul dalam situasi konflik seperti menanggapi hal-hal yang mengganggu dengan tepat.

Kompetensi sosial ini dipengaruhi oleh berbagai hal, salah satunya adalah kelekatan yang aman (Moreira, 1998). Shaffer, dkk. (2009) menjelaskan bahwa kelekatan yang aman pada masa anak-anak akan memprediksi kompetensi sosial di kemudian hari. Sementara itu kurangnya kelekatan yang aman menyebabkan kurangnya keterampilan sosial, yang terlihat dari kurang mampu menyelesaikan konflik interpersonal, kemampuan berkomunikasi dan lain-lain (Mallinckrodt \& 
Wei, 2005).

Kelekatan terhadap orangtua pada masa remaja dapat membantu kompetensi sosial dan kesejahteraan sosial remaja (Santrock, 2007), yang terlihat dari tingginya harga diri, memiliki penyesuaian emosional, dan kesehatan fisik (Desmita, 2012). Collins dan Feeney (dalam Desra, 2014) menjelaskan bahwa individu yang mengalami kelekatan yang aman adalah individu yang selalu percaya bahwa dirinya dicintai dan dihargai oleh orang lain dan mendapat perhatian penuh, menilai figur lekat sebagai responsif, penuh perhatian dan dapat dipercaya, merasa nyaman jika dalam sebuah kedekatan atau keintiman, selalu bersikap optimis dan percaya diri, dan mampu membina hubungan dekat dengan orang lain.

Ibu menduduki peringkat pertama sebagai figur lekat utama anak, ibu biasanya lebih banyak berinteraksi dengan anak dan berfungsi sebagai orang yang memenuhi kebutuhannya serta memberikan rasa nyaman (Eliasa, 2011). Kebutuhan akan kelekatan (attachment) pada ibu menjadi hal penting dalam kehidupan individu karena merupakan suatu langkah awal dalam proses perkembangan dan sosialisasi (Liliana, 2009). Selain ibu, peranan ayah juga sangat penting untuk kehidupan anak-anaknya (Dagun, 2002). Ayah juga mempunyai peranan penting dalam penentuan status kelekatan anak, apakah anak akan membentuk kelekatan aman atau sebaliknya (Ekasari dan Bayani, 2009). Keterlibatan ayah dalam pengasuhan anak berhubungan dengan pencapaian akademik, kompetensi sosial, dan harga diri anak-anak mereka (Rice dalam Ekasari dan Bayani, 2009).

Bowlby (dalam Upton, 2012) mengungkapkan bahwa kelekatan merupakan hubungan psikologis antar manusia, yang terbentuk semenjak awal kehidupan anak, yang terjadi antara anak dengan pengasuh, dan memiliki dampak pada pembentukan hubungan yang berlangsung sepanjang hidup.

Armsden, dkk. (1990) dan Gullone dan Robinson (2005) berdasarkan teori kelekatan Bowlby di atas membagi kelekatan menjadi dua pola kelekatan yaitu kelekatan yang aman (secure attachment) dan keleka- tan yang tidak aman (insecure attachment). Kelekatan yang aman terbagi menjadi dua dimensi yakni kepercayaan (trust) dan komunikasi (communication). Kelekatan yang tidak aman ditandai dengan adanya dimensi terkucilkan (allienation). Kemudian Armsden dan Greenberg (2009) menyusun skala kelekatan berdasarkan teori tersebut yang diberi nama Inventory Parent and Peer Attachment (IPPA).

Kelekatan yang aman antara anak dengan orangtua ditandai dengan adanya rasa saling percaya dan komunikasi yang hangat antara anak dengan orangtua. Individu yang diklasifikasikan memiliki kelekatan yang aman memiliki skor yang tinggi untuk dimensi kepercayaan dan komunikasi, dan skor yang rendah pada dimensi perasaan terkucilkan. Kepercayaan mengacu pada kepercayaan remaja bahwa orangtua memahami dan menghormati kebutuhan dan keinginan mereka. Sedangkan komunikasi mengacu pada persepsi remaja bahwa orangtua akan sensitif dan responsif terhadap keadaan emosional mereka dan menilai sejauhmana kualitas keterlibatan dan komunikasi verbal dengan mereka.

Kelekatan yang tidak aman ditandai dengan adanya dimensi terkucilkan. Individu yang memiliki kelekatan yang tidak aman menunjukkan skor kepercayaan dan komunikasi yang rendah dan skor rasa terkucilkan yang tinggi. Keterkucilan mengacu pada perasaan remaja yang terisolasi, kemarahan, dan pengalaman ketidak-dekatan (detachment) dengan orangtua.

Individu yang memiliki kelekatan yang aman (secure attachment) akan menunjukkan bermacam-macam karakteristik positif, seperti menjadi lebih pintar dalam menyelesaikan masalah dan lebih memiliki kompetensi sosial, seperti lebih kooperatif, patuh pada orangtua dan memiliki hubungan yang lebih baik dengan teman sebayanya (Retnaningsih, 2005). Individu yang memiliki kompetensi sosial yang tinggi memiliki hubungan yang kuat dengan orangtua mereka, memiliki komunikasi yang baik, tidak merasa diasingkan dan mengalami konflik yang sedikit dengan orangtua. Begitu juga mereka cenderung memiliki kualitas persahabatan yang lebih baik, 
merasa bahwa teman-teman mereka akan memberikan dukunngan emosional dan material dan mereka merasa tidak diasingkan dari teman-teman (Smart \& Sanson, 2003).

Kelekatan ibu dan anak merupakan respon biologis yang sangat penting dalam perkembangan anak di masa mendatang (Bowlby, Klaus \& Kennell, dalam Hendrianti, 1996). Liliana (2009) menyatakan bahwa ibu memiliki peran dan tanggung jawab penuh meyakinkan bahwa anak "berada pada jalan yang benar" sehingga ibu memiliki penekanan pada pentingnya membawa anak dalam lingkungan yang tepat.

Anapratiwi, dkk (2013) yang menyatakan bahwa anak yang memiliki kelekatan aman pada ibu akan memiliki kemampuan sosialisasi yang baik, lebih mudah bersahabat, memiliki hubungan yang sehat, dan mudah beradaptasi dengan lingkungan sosial karena percaya lingkungan yang mereka tempati dapat memberikan kenyamanan dan keamanan. Selain ibu, ayah juga memiliki peranan yang sangat penting dalam kehidupan anak. Santrock (2007) menjelaskan bahwa peran ayah selain sebagai pencari nafkah utama dan pembimbingan moral bagi remaja, ayah juga berperan dalam mengasuh anaknya. Ekasari dan Bayani (2009) menjelaskan bahwa sebagai pengasuh anak, ayah memegang peranan penting dalam penentuan status kelekatan anak, apakah anak akan membentuk kelekatan aman atau sebaliknya.

Kelekatan antara ayah dan anak berhubungan dengan sikap dan perilaku ayah yang sensitif, bukan dengan jumlah waktu keterlibatan (Ekasari dan Bayani, 2009). Kualitas kelekatan yang terjalin antara remaja dan ayah dapat memberikan pengaruh dalan kehidupan sosial remaja. Sebagaimana Carlson \& Mc Lanahan, 2002; Jones, 2006; Parke, 2002 (dalam Santrock, 2007) bahwa interaksi dengan ayah yang mengasihi, mudah berkomunikasi, dan dapat diandalkan dapat memberikan kepercayaan dan keyakinan pada anak-anaknya sehingga akan mendukung perkembangan sosial remaja.

Jadi, berdasarkan uraian diatas peneliti ingin mengetahui hubungan antara kelekatan (attachment) pada ibu dan ayah dengan kompetensi sosial pada remaja. Adapun hipotesis yang diajukan ada tiga yaitu:

1. Terdapat hubungan antara kelekatan (attachment) pada ibu dan ayah dengan kompetensi sosial pada remaja.

2. Terdapat hubungan antara kelekatan (attachment) pada ibu dengan kompetensi sosial pada remaja.

3. Terdapat hubungan antara kelekatan (attachment) pada ayah dengan kompetensi sosial pada remaja

\section{Metode}

\section{Subjek}

Subjek dalam penelitian ini adalah remaja di SMPN 21 Pekanbaru yang berusia 12-15 tahun dan masih memiliki kedua orangtua. Jumlah subjek penelitian adalah adalah 199 orang remaja.

\section{Pengukuran}

Variabel yang digunakan dalam penelitian ini adalah kompetensi sosial dan kelekatan pada ibu dan ayah. Skala komptensi sosial yang disusun berdasarkan aspek dari Gresham dan Elliott (dalam Smart dan Sanson, 2003) yaitu asertif, kooperatif, empati, tanggung jawab, dan pengendalian diri. Dan skala kelekatan pada ibu dan ayah yang digunakan adalah Inventory Parent and Peer Attachment (IPPA) yang disusun oleh Armsden dan Greenberg (2009). Pada skala ini, kelekatan pada ibu dan ayah diukur secara terpisah. Skala ini juga pernah digunakan oleh Guarnieri, Ponti dan Tani (2010) dan Farliani (2012). Selanjutnya skala IPPA ini diterjemahkan dan diujicobakan oleh oleh Wahyuni dan Asra (2014). Adapun aspek yang diukur adalah yaitu kepercayaan antara remaja dan orangtua (parent trust), komunikasi antara remaja dan orangtua (parent communication), dan rasa keterasingan (parent alieanation).

\section{Analisis Data}

Analisis data yang digunakan dalam penelitian ini menggunakan analisis korelasi regresi linier berganda dan korelasi product moment Pearson. Analisis korelasi regresi linear berganda bertujuan untuk melihat apa- 
kah kedua variabel bebas secara bersamasama berkorelasi dengan dengan variabel tergantung, sedangkan korelasi product moment Pearson bertujuan untuk melihat korelasi masing-masing variabel bebas terhadap variabel tergantung.

\section{Hasil}

\section{Uji Hipotesis}

Berikut ini adalah hasil uji hipotesis pertama yaitu "terdapat hubungan antara kelekatan (attachment) pada ibu dan ayah dengan kompetensi sosial pada remaja".

Tabel 1 Uji Korelasi Product Moment

Variabel

Kelekatan pada ibu- Kompetensi sosial

Kelekatan pada ayah - Kompetensi sosial

Berdasarkan hasil korelasi menunjukkan bahwa kelekatan pada ibu mempunyai hubungan positif dengan kompetensi sosial dengan $r$ sebesar $0,158, p=0,013(p<0,05)$. Kelekatan pada ayah juga mempunyai hubungan positif dengan kompetensi sosial dengan $r$ sebesar 0,162, $p=0,011(p<0,05)$.

Tabel 2 Uji Korelasi Aspek Kelekatan pada Ibu

\begin{tabular}{clll}
\hline Variabel & $\mathbf{R}$ & $\mathbf{P}$ & Taraf Signifikasi \\
\hline Kepercayaan pada ibu - Kompetensi sosial & 0,206 & 0,002 & Signifikan \\
Komunikasi pada ibu - Kompetensi sosial & 0,273 & 0,000 & Signifikan \\
Keterasingan dari ibu - Kompetensi sosial & $-0,247$ & 0,000 & Signifikan \\
\hline
\end{tabular}

Berdasarkan hasil korelasi diketahui bahwa kepercayaan pada ibu mempunyai hubungan positif dengan kompetensi sosial pada remaja dengan $r$ sebesar 0,206, $p=0,002(p<0,05)$. Komunikasi pada ibu juga mempunyai hubungan yang positif dengan kompetensi sosial pada remaja dengan $r$ sebesar 0,273, $p=0,000(p<0,05)$. Sedangkan keterasingan dari ibu mempunyai hubungan negatif dengan kompetensi sosial dengan $r$

negatif dengan kompetensi sosial dengan $r$ sebesar -0,247, $p=0,000(p<0,05)$.

Analisis Berdasarkan Aspek pada Variabel Kelekatan pada Ayah

Analisis berdasarkan aspek pada variabel kelekatan pada ayah juga dilakukan dengan menggunakan korelasi product moment dan hasilnya dapat dilihat pada tabel 3 berikut ini:

\section{Tabel 3 Uji Korelasi Aspek Kelekatan pada Ayah}

\begin{tabular}{cccl}
\hline Variabel & $\mathbf{r}$ & $\mathbf{P}$ & Taraf Signifikasi \\
\hline Kepercayaan pada ayah - Kompetensi sosial & 0,190 & 0,004 & Signifikan \\
Komunikasi pada ayah - Kompetensi sosial & 0,183 & 0,005 & Signifikan \\
Keterasingan dari ayah - Kompetensi sosial & $-0,175$ & 0,007 & Signifikan \\
\hline
\end{tabular}


Berdasarkan hasil korelasi diketahui bahwa kepercayaan pada ayah mempunyai hubungan positif dengan kompetensi sosial pada remaja dengan $r$ sebesar 0,190 , $p=0,004 \quad(p<0,05)$. Komunikasi pada ayah juga mempunyai hubungan yang positif dengan kompetensi sosial pada remaja dengan $r$ sebesar 0,183, $p=0,005(p<0,05)$. Keterasingan dari ayah mempunyai hubungan negatif dengan kompetensi sosial pada remaja dengan $r$ sebesar $-0,175, p=0,007(p<0,05)$.

\section{Uji Perbedaan Berdasarkan Jenis Kelamin}

Uji perbedaan berdasarkan jenis kelamin dianalisis dengan menggunakan uji t-test dan hasilnya dapat dilihat pada tabel 4 berikut ini:

Tabel 4 Uji perbedaan berdasarkan jenis kelamin

\begin{tabular}{llllccl}
\hline Variabel & Jenis Kelalmin & Jumlah & Mean & $\mathbf{t}$ & $\mathbf{p}$ & Signifikansi \\
\hline Kompetensi sosial & Laki-laki & 101 & 63,05 & $-3,003$ & 0,003 & Signifikan \\
& Perempuan & 98 & 66,32 & & & \\
Kelekatan pada ibu & Laki-laki & 101 & 26,34 & $-1,469$ & 0,143 & Tidak Signifikan \\
& Perempuan & 98 & 26,70 & & & \\
\multirow{2}{*}{ Kelekatan pada ayah Laki-laki } & 101 & 32,39 & $-1,495$ & 0,136 & Tidak Signifikan \\
& Perempuan & 98 & 33,01 & & & \\
\hline
\end{tabular}

Hasil uji perbedaan jenis kelamin pada tiap variabel ditemukan bahwa terdapat perbedaan kompetensi sosial yang signifikan antara laki-laki dan perempuan ( $\mathrm{t}-3.003$, p 0,003 $(p<0,05))$, tidak terdapat perbedaan kelekatan yang signifikan antara remaja lakilaki dan perempuan baik kelekatan terhadap ibu maupun terhadap ayah ( $\mathrm{t}-1,469, \mathrm{p} 0,143$ $(p>0,05)$ untuk variabel kelekatan terhadap ibu; dan t -1,495, p 0,136 ( $p>0,05)$ untuk variabel kelekatan terhadap ayah).

\section{Pembahasan}

Hasil penelitian menggunakan analisis regresi linear berganda dan menemukan bahwa kelekatan pada ibu dan ayah secara bersama-sama mempunyai hubungan positif dengan kompetensi sosial pada remaja dengan nilai $R$ sebesar 0,229 dan nilai $F$ sebesar 5,444 dengan signifikansi 0,005. Artinya semakin tinggi kelekatan pada ibu dan ayah maka semakin tinggi kompetensi sosial pada remaja.

Ibu dan ayah merupakan orangtua yang memiliki peranan yang sangat penting dalam membesarkan anak, memberikan kasih sayang pada anak serta bertanggung jawab dalam memberikan bimbingan dan pengarahan yang dapat membantu anak dalam menjalani kehidupan. Selanjutnya pada usia remaja, orangtua merupakan figur lekat utama bagi remaja, meskipun dalam kesehariannya remaja lebih banyak menghabiskan waktu bersama teman sebaya. Orangtua yang mendukung, memberikan keamanan dan kenyamanan pada remaja akan membentuk ikatan emosi yang kekal sepanjang waktu (Indrawati dan Fauziah, 2012). Kelekatan yang aman antara anak dan orangtua sangat berpengaruh terhadap kehidupan bahkan hingga dewasa (Malekpour, 2007).

Remaja yang memiliki kelekatan pada orangtua akan membentuk rasa percaya, menjalin komunikasi dan tidak merasa diasingkan atau dikucilkan oleh orangtua. Terbentuknya kepercayaan remaja pada orangtua ditunjukkan dengan remaja yang menganggap bahwa orangtua sebagai orang yang dapat dipercaya dengan memberikan perhatian, memahami keinginan remaja, dan menerima remaja dengan apa adanya. Remaja yang menjalin komunikasi dengan orangtua ditunjukkan dengan remaja yang terbuka, mengungkapkan apa yang dirasakan, mengungkapkan masalah serta kesulitan yang sedang dihadapi. Remaja yang tidak dikucilkan oleh orangtua akan memiliki kedekatan dengan orangtua yang ditunjukkan dengan adanya kepercayaan dan perhatian yang diberikan oleh orangtua. 
Kelekatan pada orangtua memiliki peran penting dalam kehidupan sosial remaja. Sebagaimana Santrock (2002) menjelaskan bahwa kelekatan (attachment) dengan orangtua selama masa remaja dapat berlaku sebagai fungsi adaptif, yang menyediakan landasan yang kokoh dimana remaja dapat menjelajahi dan menguasai lingkungan baru dan dunia sosial yang luas dengan suatu cara yang secara psikologis sehat. Anak yang memiliki kelekatan yang aman menunjukkan lebih banyak emosi positif, memiliki empati yang lebih besar, dan lebih mampu mengambil inisiatif, merespon serta melanjutkan hubungan dengan orang lain (Retnaningsih, 2005).

Rasa percaya pada orangtua dan interaksi komunikasi pada orangtua dijadikan sebagai landasan oleh remaja untuk belajar mempercayai dan menjalin komunikasi yang efektif dengan orang lain sehingga remaja dapat membangun hubungan sosial dengan orang lain (Soetjiningsih, 2012). Hubungan yang saling percaya yang merupakan wujud dari kelekatan akan membantu komptensi dan kesejahteraan sosial remaja (Santrock, 2007).

Hasil penelitian ini juga menguji secara terpisah hubungan antara kelekatan pada ibu dan ayah dengan kompetensi sosial pada remaja. Hasil dari uji hipotesis menunjukkan bahwa kelekatan pada ibu dan ayah sama-sama mempunyai hubungan positif dengan kompetensi sosial pada remaja $(r$ 0,158 p 0,013 $(p<0,05)$ untuk kelekatan dengan ibu; $r$ 0,162 p 0,011 ( $p<0,05)$ untuk kelekatan dengan ayah). Artinya semakin tinggi kelekatan pada ibu dan ayah maka semakin tinggi kompetensi sosial pada remaja.

Remaja yang mempunyai kelekatan dengan ibu menjadikan ibu sebagai sumber rasa nyaman dan aman yang ditunjukkan dengan remaja yang percaya pada ibu, remaja yang merasa nyaman ketika berada di dekat ibu dan remaja yang akan mencari ibu ketika berada dalam situasi bermasalah. Rasa kenyamanan dan keamanan yang di rasakan oleh remaja yang memiliki kelekatan pada ibu dapat membuat remaja merasa nyaman dan aman ketika berhubungan atau berinteraksi dengan orang lain dalam ling- kungan sosialnya. Hal ini dikarenakan interaksi yang terjalin antara ibu dan remaja dapat membantu remaja untuk belajar dan mengatur perilaku mereka ketika berhadapan dengan orang lain.

Hasil penelitian ini yang menemukan bahwa ada korelasi yang signifikan antara kelekatan pada ibu dengan kompetensi sosial remaja sejalan dengan penelitian yang dilakukan oleh dan Krasnor (1996) yang menemukan bahwa kelekatan yang aman antara anak dengan ibu berkorelasi dengan komptensi sosial anak. Liliana (2009) juga menemukan bahwa subjek yang menilai figur attachment adalah ibu, merupakan figur yang dapat dipercaya, selalu memperhatikan dan menyayangi subjek dimanapun, dan kapanpun subjek membutuhkannya. Selanjutnya, anak yang memiliki kelekatan yang aman akan memiliki kemampuan sosial yang baik, lebih mudah bersahabat, memiliki hubungan yang sehat, dan mudah beradaptasi dengan lingkungan sosial karena percaya lingkungan yang mereka tempati dapat memberikan kenyamanan dan keamanan (Anapratiwi, 2013). Dalam teori Bowlby dan beberapa temuan menunjukkan bahwa ibu masih terus menjadi figur utama kelekatan pada remaja diikuti oleh ayah dan teman sebaya (Laumi \& Adiyanti, 2012).

Ayah juga mempunyai peranan penting dalam penentuan status kelekatan anak, apakah anak akan membentuk kelekatan aman atau sebaliknya (Ekasari \& Bayani, 2009). Remaja yang membentuk kelekatan pada ayah ditandai dengan adanya kepercayaan remaja kepada ayah, remaja yang menghabiskan waktu bersama ayah, remaja yang tidak merasa terganggu bila berada dekat dengan ayah, dan selanjutnya akan merasa nyaman dan aman ketika berinteraksi dengan lingkungan sosialnya. Hal ini karena interaksi dengan ayah yang mengasihi, mudah berkomunikasi, dapat diandalkan, dapat memberikan kepercayaan dan keyakinan pada anak-anak dan sangat mendukung perkembangan sosial remaja (Santrock, 2007), memiliki kemampuan empati, menyesuaikan diri, dan mampu menjalin hubungan positif dengan orang lain (Shobabiya, 2014). 
Kelekatan (attachment) dapat dibagi menjadi dua pola yaitu kelekatan yang aman (secure attachment) dan kelekatan yang tidak aman (insecure attachment). Individu yang dikategorikan memiliki kelekatan yang aman memiliki skor yang tinggi pada kepercayaan dan komunikasi, serta memiliki skor yang rendah pada keterasingan. Sedangkan individu yang memiliki skor yang tinggi pada keterasingan dan skor yang rendah pada kepercayaan dan komunikasi memiliki kelekatan yang tidak aman (Guarnieri, Ponti, dan Tani, 2010). Anak yang mempunyai kelekatan yang aman menjadikan orangtuanya sebagai sumber rasa nyaman dan aman (Wahyuni dan Asra, 2014), begitu juga pada remaja, remaja yang memandang orangtua sebagai orang yang memberikan keamanan psikologis bagi remaja ditunjukkan dengan adanya komunikasi yang baik dan kepercayaan antara orangtua dan remaja (Dewi dan Valentina, 2013), karena remaja yang terikat secara aman (secure) dapat mempercayai dan terbuka dengan orang lain (Widyastuti \& Widjaja, 2004).

Namun, ketika komunikasi tidak terjalin dengan baik, anak akan merasa dikucilkan oleh orangtua sehingga mengurangi rasa aman mereka dan berangsur-angsur akan menghilangkan rasa kepercayaan mereka pada orangtua (Laumi dan Adiyanti, 2012). Sebagaimana temuan dalam penelitian ini bahwa pengucilan dari ibu dan ayah mempunyai hubungan yang negatif dengan kompetensi sosial pada remaja $(r-0,247, p 0,000$ $(p<0,05)$ pada ibu; $r-0,175, p 0,007(p<0,05)$ untuk ayah. Artinya semakin tinggi pengucilan dari ibu dan ayah maka semakin rendah kompetensi sosial pada remaja. Hasil dari analisis aitem menunjukkan bahwa tidak adanya perhatian yang ditunjukkan ibu pada remaja dan ibu yang kurang responsif dapat membuat remaja merasa diasingkan atau dikucilkan sehingga remaja tidak dapat merasa nyaman dan aman. Perasaan dikucilkan dari ibu dan ayah dapat membuat remaja sulit dalam berinteraksi dengan orang lain dan akan cenderung menjadi pribadi yang narsistik dan kurang mampu dalam menjalin interaksi sosial (Retnaningsih, 2005). Menurut Shobabiya (2014) remaja yang memiliki hubungan tidak baik dengan ayahnya akan lebih pesimis dan tidak mempunyai kemampuan untuk bertanggung jawab dalam kehidupannya.

Hasil kategorisasi subjek pada penelitian ini menunjukkan bahwa kelekatan pada ibu berada kategori tinggi $(34,71 \%)$, sedangkan kelekatan pada ayah berada pada kategori sedang $(38,19 \%)$. Artinya sebagian remaja memiliki kelekatan pada ibu pada kategori tinggi, sedangkan kelekatan pada ayah berada pada kategori sedang. Pada penelitian ini juga ditemukan bahwa sebagian remaja memiliki kompetensi sosial pada kategori sedang (39,19\%). Artinya remaja cukup mampu membina hubungan yang baik dengan orang lain.

Pada penelitian ini ditemukan bahwa bahwa kontribusi kelekatan pada ibu dan ayah terhadap kompetensi sosial pada remaja adalah $5,3 \%$ (Rsq 0,053), sedangkan sisanya yaitu $94,7 \%$ dipengaruhi oleh faktor-faktor lain. Hal ini dikarenakan dalam perkembangan kehidupannya, individu dipengaruhi oleh lima aspek lingkungannya yaitu mikrosistem, mesosistem, ekosistem, makrosistem, dan kronosistem (Bronfenbrenner, dalam Upton, 2012). Berdasarkan hasil uji t-tes pada variabel kompetensi sosial ditemukan bahwa terdapat perbedaan kompetensi sosial yang signifikan antara remaja laki-laki dengan remaja perempuan, remaja perempuan memiliki kompetensi sosial yang lebih tinggi dibanding remaja laki-laki ( $t-3,003, p 0,003(p<0.05)$; rerata kompetensi remaja perempuan 66,32, dan remaja laki-laki 63,05).

Tingginya kompetensi sosial pada remaja perempuan dikarenakan remaja perempuan mempunyai sifat yang cenderung patuh dan menerima aturan-aturan yang berlaku dalam keluarga dan masyarakat, lebih mudah menghayati perasaan orang lain dan labih senang menciptakan hubungan yang lebih erat dengan teman sebaya (Wardani dan Apollo, 2012). Hasil penelitian ini berbeda dengan penelitian sebelumnya yang dilakukan oleh Rahman (2010) yang mengatakan bahwa kompetensi sosial pada subjek laki-laki memiliki nilai yang lebih tinggi dibandingkan dengan subjek perempuan. 
Selanjutnya, hasil uji t-tes menemukan bahwa tidak terdapat perbedaan yang signifikan kelekatan pada ibu dan ayah antara remaja laki-laki dan remaja perempuan ( $\mathrm{t}-1,469$, $\mathrm{p}$ $0,143(p>0,05)$ kelekatan pada ibu; $t-1,495$ p $0,136(p>0,05)$ kelekatan pada ayah). Artinya remaja laki-laki dan remaja perempuan mempunyai kesempatan yang sama untuk membangun hubungan yang dekat baik dengan ibu maupun dengan ayah. Sebagaimana yang dijelaskan oleh Kuntianty dan Nuraya (2005) bahwa tidak ada perbedaan gaya kelekatan aman pada ibu antara remaja laki-laki dan remaja perempuan dan gaya kelekatan aman pada ayah antara laki-laki dan perempuan.

\section{Kesimpulan}

Terdapat hubungan yang signifikan antara kelekatan pada ibu dan ayah dengan kompetensi sosial pada remaja, artinya semakin tinggi kelekatan pada ibu dan ayah maka semakin tinggi kompetensi sosial pada remaja. Tidak terdapat perbedaan kelekatan pada ibu dan ayah antara remaja laki-laki dan remaja perempuan. Dan kompetensi sosial pada remaja perempuan lebih tinggi dibandingkan remaja laki-laki.

\section{Daftar Pustaka}

Anapratiwi, D, Handayani, D. S. S dan Kurniawati, Y. (2013). Hubungan antara kelekatan anak pada ibu dengan kemampuan sosialisasi anak usia 4-5 tahun (Studi Pada RA Sinar Pelangi dan RA Al Iman Kecamatan Gunung Pati, Semarang). Semarang: Early Childhood Education Papers (Belia).

Anindyajati, M \& Karima, C.M. (2004). Peran Harga Diri terhadap Asertivitas Remaja Penyalahguna Narkoba (Penelitian pada Remaja Penyalahguna Narkoba di tempat-tempat Rehabilitasi Penyalahguna Narkoba). Jurnal Psikologi 2 (1), 49-73.

Anggraini, D.R. \& Wahyuningsih, H. (2007). Hubungan antara Intensitas Bermain
Game Online dengan Kompetensi Sosialpada Remaja. Naskah Publikasi Skripsi. Yogyakarta: Fakultas Psikologi UII.

Arsmden, G. C., McCauley, E., Greenberg, M.T., Burke, P. M., dan Mitchell, J.R. (1990). Parent and peer attachment in early adolescent depression. Journal of Abnormal Child Psychology, 18 (6), 683-697.

Armsden, G.,\& Greenberg, M.T. (2009). Inventory of Parent and Peer Attachment (IPPA).College of Health and Human Development.Ditemu kembali dari http://www.prevention. psu.edu/media/prc/files/IPPAManual December2013.pdf.

Dagun, S. M. (2002). Psikologi Keluarga (Peran Ayah dala Keluarga). Jakarta: PT Rineka Cipta

Desmita. (2012). Psikologi Perkembangan. Bandung : PT Remaja Rosada

Desra, R. (2014). Hubungan Kelekatan Terhadap Guru Dengan Motivasi Menghapal Al-Qur'an Pada Siswa SMPIT Al-Ihsan Boarding School Pekanbaru. Skripsi. Pekanbaru: Fakultas Psikologi UIN Suska Riau.

Dewi, A.A. \& Valentina, T. D. (2013). Hubungan Kelekatan OrangtuaRemaja dengan Kemandirian pada Remaja di SMKN 1 Denpasar. Jurnal Psikologi Udayana, 1 (1), 181-189.

Ekasari, A dan Bayani, 1. (2009). Attachment pada Ayah dan Penerimaan Peer Group dengan Resiliensi (Studi Kasus pada Siswa Laki-laki di Tingkat Sekolah Menengah Pertama). Jurnal Soul, 2 (2).

Eliasa, E. I. (2011). Pentingnya Kelekatan Orangtua dalam Internal Working Model untuk pembentukan Karakter Anak (Kajian Berdasarkan Teori Kelekatan dari John Bowlby). dalam Karakter Sebagai Saripati Tumbuh Kembang Anak Usia Dini, Yogyakarta: Inti Media Yogyakarta bekerjasama dengan Pusat Studi Pendidikan Anak Usia Dini Lembaga Penelitian Universitas Negeri Yogyakarta.

Farliani, A. B. (2012). Hubungan antara Parental Attachment, Peer Attachment, dan Psychologycal Well-Being pada Mahasiswa Tahun Pertama di Universitas Indonesia. 
Skripsi. Jakarta: Fakultas Psikologi Universitas Indonesia.

Guarnieri, S., Ponti, L., \& Tani, F. (2010). The Inventory of Parent and Peer Attachment (IPPA): A Study on the Validity of Styles of Adolescent Attachment to Parent and Peer in an Italian Sampel. TPM, 17 (3), 103130.

Gullone, E. \& Robinson, K. (2005). The Inventory of Parent and Peer Attachment-Revised (IPPA-R) for Chlidren: A Psychometric Investigation. Clinical Psychology and Psychotherapy 12, 67-79.

Hair, E. C. Jagger, J. \& Garrett, S. (2001). Background for Community Level Work on Social Competency in Adolescence: Reviewing the Literatur Contributing Factors. Trend Child: Prepared for the John S and James L. Knight Foundation

Hendriati, A. (1996). Meninjau Kembali Pentingnya Kelekatan Ibu-Anak. Jakarta: ATMA nan JAYA.

Indrawati, S. E \& Fauziah, N. (2012). Attachment dan Penyesuaian Diri dalam Perkawinan. Jurnal Psikologi Undip, 11 (1), 40-49.

Kuntianty \& Nuraya, K. (2005). Kemandirian ditinjau dari Gaya Kelekatan Aman dan Urutan Kelahiran pada Remaja. Naskah Publikasi Skripsi. Yogyakarta: Fakultas Psikologi UII.

Krasnor, L.R dkk. 1996. The Relation of Maternal Directiveness and Child Attachment Security to Social Competence in Preschool ers. International Journal Of Behavioral Development 19 (2), 309-325

Laumi \& Adiyanti, M. G. (2012). Attachment of Adolescent to Mother, Father, Peer, with Family Structure as Moderating Variabel and Their Relationships with Self esteem. Jurnal Psikologi, 39 (2), 129-142.

Liliana, A. W. (2009). Gambaran Kelekatan (Attachment) Remaja Akhir Putri dengan Ibu (Studi Kasus). Skripsi. Jakarta: Universitas Gunadarma.

Mallinckrodt, B. \& Wei. M. (2005). Attachment, Social Competence, Social Support, and Psychological Distress. Journal of Counseling Psychology . 52 (3), 358367

Malekpour, M. (2007). Effects of Attachment on Early and Later Development. The British Journal of Developmental Disabilities Vol 53 Part 2 No. 105. pp 81-95
Moreira, J. M., Bernardes, S., Andrez, M., Aguiar, P., Moleiro, C., \& Maria de Fatima Silva , M. d. F. (1998). Social Competence, Personality And Adult Attachment Style In A Portuguese Sample. Indigd. Diff. 24 (4), 565-570.

Papalia, D. E., Old, S. W., \& Feldman, R. D. (2008). Human Development: Psikologi Perkembangan Edisi Kesembilan Bagian V s/d IX. Jakarta: Kencana Prenada Media Group.

Pekanbaru Tribun.com. (2012). Enam Kejahatan Kian Meningkat di Ibukota. Diunduh 20 Mei 2015. http://pekanbaru.tribunnews.com/2012/12/30/ enam-kejahatan-kian-meningkat-diibukota.

Rahman, F. (2010). Hubungan Egosentris dengan Kompetensi Sosial Remaja Siswa SMP Muhammadiyah 22. Skripsi. Pamulang: Fakultas Psikologi Universitas Setia Budi.

Republika.co.id. 2013. Memprihatinkan Remaja sekarang malah jadi Maling. Diunduh 2Juni2015.http:// republika.co.id/2013/12/10/ memprihatinkan-remaja. Sekarangmalah-jadi-maling.

Retnaningsih. (2005). Peranan Kualitas Aitachment, Usia Dan Gender Pada Perilaku Prososial. Jakarta: Seminar Nasional Universitas Gunadarma.

Renk, K. \& Phares, V. (2004). Crossinformant rating of social competence in children and adolescents. Clinical Psychology Review (24) 239-254.

Santrock, J. W. (2002). Life Span Development Perkembangan Masa Hidup Edisi ke lima Jilid 11. Jakarta: Erlangga.

Santrock, J.W. (2007). Remaja Edisi 11 Jilid 2. Jakarta: Erlangga

Santoso, S. W. (2011). Keterlibatan, Keberhargaan, dan Kompetensi Sosial sebagai Prediktor Kompetensi pada Remaja. Jurnal Psikologi, 38 (1),: 52-60.

Sindonews.com. 2014. Memprihatinkan Kasus Penyalahgunaan Narkoba oleh Remaja. Diunduh 2 Juni 2016.http:// sindonews.com/2014/11/6/memprihatinkan-kasus-penyalahgunaannarkoba-oleh-remaja.

Shaffer, A., Burt, K. B., Obradovic, J., Herbers, J. E., \& Masten, A., (2009). Intergenerational Continuity in Parenting Quality: The Role of Social Competence. Developmental Psychology, 45 (5), 1227-1240.

Shobabiya, M. (2014). Hubungan antara Kelekatan Orangtua dengan Resiko Penyalahgunaan NAPZA pada Remaja. Naskah Publikasi Skripsi. 
Surakarta: Fakultas Psikologi Wahyuni, S. \& Asra, Y. K. (2014). Universitas Muhammadiyah Kecenderungan Anak Menjadi Pelaku Surakarta.

Smart, D. \& Sanson, A. (2003). Social Competence in Young Adulthood Its Nature and Atencendents. Familiy Matters Autumn, 64, 4-9.

Soetjiningsih, C. H. (2012). Perkembangan Anak Sejak Pembuahan sampai dengan Kanak-kanak akhir. Jakarta: Prenada Media Group.

Tempo.co.id. (2015). Pengeroyok siswa SMK 2 di depok dibekuk. Diunduh 21 Oktober $2015 \mathrm{http}: / /$ metro.tempo. $\mathrm{co} / \mathrm{read} / \mathrm{news} / 2015 / 09 / 21 / 064702501 /$ 2 pengeroyok-siswa-smk-2-di-depokdibekuk.

Upton, P. (2012). Psikologi Perkembangan. dan Korban Bullying ditinjau dari Kualitas Kelekatan dengan Ibu yang Bekerja. Jurnal Kajian Gender dan Islami, 13, 1-24.

Wardani, R \& Apollo. (2012). Hubungan antara Kompetensi Sosial dengan Penyesuaian Sosial pada Remaja. Widya Warta No 1 Tahun XXXIV

Widyastuti, N \& Widjaja, T. (2004). Hubungan antara Kualitas Relasi Ayah dengan Harga Diri Remaja Putra. Jurnal Psikologi, 2 (1), 22-43.

Yusuf, S. (2012). Psikologi Perkembangan Anak dan Remaja. Bandung: PT Remaja Rosada. Jakarta : Erlangga 